\begin{tabular}{|c|c|}
\hline 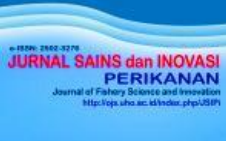 & $\begin{array}{c}\text { JURNAL SAINS dan INOVASI PERIKANAN } \\
\text { Journal of Fishery Science and Innovation } \\
\text { e-ISSN: } 2502-3276\end{array}$ \\
\hline $5=$ & $\begin{array}{c}\text { Vol. 3, No.1, 26-31, Januari } 2019 \\
\text { http://ojs.uho.ac.id/index.php/JSIPi }\end{array}$ \\
\hline
\end{tabular}

\title{
Potensi Ekstrak Steroid dari Teripang Pasir (Holothuria scabra) dari Perairan Atowatu Kendari untuk Pengendalian Bakteri Vibrio harveyi
}

\section{The Potency of Steroid Extracts of Sea-Cucumber (Holothuria scabra) Collected from Atowatu Coast of Kendari to Control Vibrio harveyi}

\author{
Indriyani Nur ${ }^{\left.1)^{*}\right)}$, Asnani $^{2)}$, Yusnaini ${ }^{3)}$ \\ 1)Jurusan Budidaya Perairan, Fakultas Perikanan dan Ilmu Kelautan, Universitas Halu Oleo, Kendari, Indonesia \\ ${ }^{2)}$ Jurusan Teknologi Hasil Perikanan, FPIK, Universitas Halu Oleo, Kendari, Indonesia \\ ${ }^{3)}$ Program Studi Ilmu Perikanan, Universitas Halu Oleo, Kendari, Indonesia \\ *Corresponding author : indriyani_nur@uho.ac.id
}

\begin{abstract}
Sea-cucumber represent one of the marine invertebrate which is abundance, especially in the coastal water of Atowatu Sub-Province of Kendari.This aquatic animal was predicted to have potency in yielding steroid bioactive which was able to be exploited as antibacterial, especially for the control prawn luminous vibriosis disease caused by $V$. harveyi. Quantification of a steroid compound and zona inhibition of $V$. harveyi were the parameters of this research. A steroid compound obtained from sea-cucumber $(0.065 \%)$ extraction could inhibit by in vitro the growth of $V$. harveyi bacterium until the lowest dosage tested $(10 \mathrm{ppm})$. Inhibition of $V$. harveyi bacteria on steroid extract 10 to $5000 \mathrm{ppm}$ showed no difference, but significant differences at the highest dosage (10000 ppm).
\end{abstract}

Keywords: Sea-cucumber (Holothuria scabra), steroid, Vibrio harveyi, zona inhibition

\begin{abstract}
ABSTRAK
Teripang pasir merupakan salah satu invertebrata laut yang cukup melimpah terutama di perairan pantai Atowatu Kabupaten Kendari. Hewan akuatik ini diduga memiliki potensi besar dalam menghasilkan bioaktif steroid yang dapat dimanfaatkan sebagai antibakteri, khususnya untuk pengendalian penyakit kunang-kunang pada udang yang disebabkan oleh bakteri Vibrio harveyi. Kuantifikasi bahan aktif dari hasil ekstraksi dan pengujian penghambatan bahan tersebut terhadap bakteri $V$. harveyi adalah parameter dari penelitian ini. Hasil penelitian menunjukkan bahwa teripang pasir $H$. scabra yang diekstrak mengandung bahan aktif steroid $(0.065 \%)$ dan mampu menghambat pertumbuhan bakteri $V$. harveyi hingga dosis minimum yang diujikan yakni $10 \mathrm{ppm}$ secara in vitro. Daya hambat terhadap bakteri $V$. harveyi pada ekstrak steroid 10 hingga 5000 ppm tidak menunjukkan perbedaan, namun perbedaan yang signifikan terdapat pada dosis $10000 \mathrm{ppm}$.
\end{abstract}

Kata kunci: Steroid, teripang pasir (Holothuria scabra),Vibrio harveyi, zona hambat

DOI: http://dx.doi.org/10.33772/jspi.v3n1.

\section{PENDAHULUAN}

Tingginya angka kematian udang terutama dalam pemeliharaan di tambak akibat serangan penyakit vibriosis menjadi masalah bagi para pembudidaya bahkan dapat menyebabkan kerugian besar karena kematian massal udang. Salah satu upaya pengendalian penyakit yang aman dan ramah lingkungan adalah dengan penggunaan bahan alami, seperti senyawa bioaktif organisme. 
Telah ditemukan beberapa senyawa bioaktif yang terdistribusi atas golongan biota laut dan telah terbukti merupakan sumber senyawa bioaktif yang sangat baik. Produk senyawa bioaktif organisme hayati laut diantaranya mempunyai aktivitas antimikroba, antivirus, antikanker, dan sebagainya. Beberapa penelitian dalam bidang perikanan pantai telah berhasil mengisolasi dan memanfaatkan senyawa anti infeksi yang berasal dari biota laut bunga karang (sponge), hydrozoan, makroalga,dan mikroorganisme untuk kepentingan penanggulangan penyakit. Senyawa bioaktif yang diperoleh dari sponge antara lain golongan asam fenolat, steroid, terpenoid, polisakarida, dan peptida. Senyawa tersebut bahkan menunjukkan kemampuan antimikroba lebih kuat daripada antibiotik atau bahan kimia yang beredar di pasaran (Parenrengi et al., 2002; Abad et al., 2011 ).

Steroid glikosida merupakan senyawa yang terdistribusi secara alami dan luas pada banyak organisme terestrial dan laut. Beberapa penelitian yang telah mengekstrak bahan aktif steroid dari berbagai biota laut antara lain, Riris (1994) mengestrak steroid dari kerang hijau, demikian pulaIbrahim (2001) mengekstrak steroid dari lintah laut. Biota laut yang lain yang terbukti mengandung steroid adalah sponge, soft coral, dan mikroalga (Abad et al., 2011) dan telah menunjukkan aktifitas antifungi dan antibakteri.

Organisme ekinodermata secara alamiah jugamengandung metabolit sekunder yang bersifat antimikrobial. Screening antibakterial pada tiga spesies teripang, yakni Holothuria atra, H. scabra dan Bohadschia argus dari perairan pantai Sabah Malaysia menunjukkan kemampuannya menghambat pertumbuhan beberapa bakteri gram positif dan bakteri gram negatif (Ridzwan et al., 1995). Ekstrak alkohol teripang $H$. atra dari perairan pantai Timur India dapat menghambat bakteri patogen pada manusia, seperti Klebsiella pneumonia, Escherichia coli, Listeria monocytogenes, Serratia liquefaciens, dan Staphylococcus aureus. Selain menunjukkan penghambatan terhadap bakteri, ekstrak juga menunjukkan aktifitas larvasidal yang baik dengan toksisitas rendah sehingga berpotensi untuk dimanfaatkan bagi organisme. Hal ini dimungkinkan karena adanya senyawa yang dikandungnya, seperti triterpene glycosida dan aglycon (Dhinakaran dan Lipton, 2014). Penelitian ini sejalan dengan yang dihasilkan oleh Gowda et al., (2008) pada ekstrak teripang ( $H$. scabra) yang menunjukkan aktifitas antibakterial dengan spektrum yang kuat terhadap bakteri gram negatif dan positif seperti E.coli, Staphylococcus sp., dan Proteus vulgaris. Uma dan Parvathavarthini (2010) juga menemukan bahwa ekstrak hexane pada teripang Temnopleurus alexandri menunjukkan aktifitas antibakteri terhadap beberapa bakteri, dan komponen ekstrak ini umumnya diidentifikasi sebagai Pentadecane, Heptadecane, Eicosane, Heneicosane, Docosane. Senyawa tersebut tampaknya yang menyebabkan sifat antibakterial dari ekstrak T. alexandri.

Senyawa bahan aktif yang dikandung oleh teripang $H$. atra, selain memiliki kemampuan antifungal dan antibakterial, juga memiliki efek sitotoksik pada konsentrasi tertentu, olehnya perlu mengkaji lebih jauh pemanfaatan ekstrak bahan aktif tersebut pada organisme budidaya. Mohammadizadeh et al., (2013) menguji efek sitotoksik ekstrak metanol dari gonad teripang tersebut terhadap Artemia (brine shrimp) dan mendapatkan konsentrasi lethal (LC50 $=50.5 \mu \mathrm{g} / \mathrm{mL}$ ).

Teripang pasir (H. scabra) merupakan salah satu invertebrata laut yang juga cukup melimpah di perairan pantai Sulawesi Tenggara, termasuk di perairan pantai Atowatu Kabupaten Kendari. Hewan akuatik ini diduga memiliki potensi besar dalam menghasilkan bioaktif steroid seperti pada biota akuatik lainnya yang dapat dimanfaatkan sebagai antibakteri, khususnya untuk pengendalian penyakit kunang-kunang pada udang yang disebabkan oleh bakteri $V$. harveyi.

Penelitian ini bertujuan mengkuantifikasi steroid dari hasil ekstraksi teripang pasir serta mengkaji kemampuan bahan aktif steroid dalam mengendalikan infeksi bakteri patogen $V$. harveyi melalui pengamatan penghambatannya secara in vitro. Eksplorasi senyawa bioaktif dari organisme bahari di Indonesia terutama di wilayah Sulawesi Tenggara perlu dilakukan untuk pemanfaatan sumber daya non konvensional termasuk isolasi/ekstraksi dan identifikasi bioaktif. Kemungkinan diperoleh berbagai senyawa bioaktif dapat digunakan untuk kebutuhan farmasi maupun untuk pengendalian penyakit khususnya penyakit pada udang windu yang sering menjadi permasalahan di hatchery maupun di tambak dimana kerap terjadi kematian udang secara massal sebagai akibat serangan penyakit vibriosis atau udang menyala. 
28 Indriyani Nur et al.

JURNAL SAINS dan INOVASI PERIKANAN / Journal of Fishery Science and Innovation

Vol. 3, No. 1, 26-31, Januari 2019

\section{METODE PENELITIAN}

Koleksi Sampel. Pengambilan sampel pada perairan pantai Atowatu Kendari dan selanjutnya dilakukan identifikasi. Ukuran panjang teripang berkisar $15-22$ $\mathrm{cm}$.Teripang pasir dibersihkan dengan mengeluarkan saluran pencernaannnya dan dikeringkan.

Ekstraksi Steroid. Ekstraksi steroid dilakukan berdasarkan metode yang dilaporkan oleh Tauchstone dan Kasparov (1970) yang telah dimodifikasi oleh Ibrahim (2001). Sebanyak 20 g teripang pasir kering dihaluskan dengan blender dan disaring hingga mendapatkan serbuk teripang. Kemudian ditambahkan $45 \mathrm{ml}$ aseton dingin dan disimpan selama 24 jam dalam kamar dingin bersuhu $4{ }^{\circ} \mathrm{C}$, selanjutnya disentrifus pada 5000 rpm selama 10 menit. Endapan yang diperoleh dipisahkan dari fase cairnya. Fase cairnya kemudian diuapkan dalam penangas air pada suhu $40{ }^{\circ} \mathrm{C}$. Residu yang diperoleh dipartisi atau diekstraksi 2 kali dalam larutan etil asetat, kloroform dan air (1:1:1) dengan menggunakan corong pisah sehingga terbentuk dua lapisan. Larutan pengestrak (lapisan bawah, kloroform, dan etil asetat) diuapkan dalam penangas air pada suhu $40{ }^{\circ} \mathrm{C}$ sampai kering. Ekstrak yang diperoleh ini kemudian digunakan untuk identifikasi steroid dan untuk uji antibakterial secara in vitroekstrak dilarutkan dalam physiological buffer saline (PBS) sesuai dengan konsentrasi yang diujikan.

\section{Identifikasi Steroid}

Identifikasi steroid dilakukan dengan uji Liebermann Burchard yaitu penambahan beberapa tetes asam asetat anhidrat dan 0,5 ml kloroform pada sedikit ekstrak teripang pasir, lalu diaduk. Selanjutnya ditambahkan satu tetes asam sulfat pekat. Timbulnya warna hijau menunjukkan bahwa ekstrak tersebut positif mengandung steroid (Cook, 1958 yang telah dimodifikasi oleh Ibrahim, 2001).

\section{Uji penghambatan tumbuh bakteri.}

Uji kemampuan antibakteri dari steroid hasil ekstraksi teripang pasir dilakukan melalui uji penghambatan dengan metode kertas cakram KirbyBauer. Kertas cakram dibuat dari kertas saring Whatmann no. 42 dengan daya serap $25 \mu$ l.Sediaan bakteri $V$. harveyi yang telah diencerkan hingga kepadatannya $\pm 10^{6} \mathrm{cfu} / \mathrm{ml}$ dalam larutan garam fisiologis diambil sebanyak $0,1 \mathrm{ml}$ lalu disebar merata pada media agar Muller Hinton dengan alat penyebar steril spreader. Selanjutnya diletakkan kertas cakram steril yang berdiameter $6 \mathrm{~mm}$ yang telah dicelupkan dalam larutan sampel bahan aktif steroid dengan konsentrasi tertentu $(0,10,100,500,1000,5000$ dan 10000 ppm) di atasnya. Sebagai kontrol positif kertas cakram lain dicelupkan pada antibiotik Erythromicin 10 ppm. Biakan bakteri tersebut pada media agar tersebut diinkubasi selama 24 jam pada suhu kamar. Respon antibakteri ditentukan dengan mengukur zona bebas bakteri di sekeliling kertas cakram yang kelihatan bening dan diukur luas daerah hambatannya (Lay, 1994).

Analisis Data

Zona hambat bebas bakteri (clear zone) pada setiap dosis ekstrak steroid dianalisis ragam, jika ada pengaruh dosis terhadap diameter zona hambat. Untuk mengetahui perbedaan antar perlakuan, maka dilanjutkan dengan uji lanjut Beda Nyata Terkecil (LSD) dengan menggunakan software SPSS 11.5

\section{HASIL DAN PEMBAHASAN}

\section{Ekstrak Steroid dari Teripang Pasir}

Serbuk teripang pasir yang diekstraksi dengan aseton-etil asetat-kloroform menghasilkan rendemen berwarna kuning kecoklatan setelah pelarutnya diuapkan dengan penangas. Rendemen yang diperoleh sebanyak $0.065 \%$. Dalam hal ini dari teripang pasir yang dihaluskan sejumlah $20 \mathrm{~g}$, diperoleh serbuk steroid sebanyak sebanyak $13 \mathrm{mg}$. Ketika diuji untuk membuktikan apakah mengandung senyawa setroid, diperoleh hasil positif atau terjadi perubahan warna zat uji menjadi hijau.

\section{Sensitifitas Bakteri Vibrio harveyi}

Berdasarkan hasil uji hambat difusi agar metode Kirby-Bauer untuk mengetahui sensitifitas bakteri $V$. harveyi terhadap bahan aktif steroid, tampak bahwa bahan aktif tersebut mempunyai potensi untuk menghambat pertumbuhan $V$. harveyi. Hal ini dapat dilihat dari zona hambat bebas bakteri (clear zone) yang terbentuk di sekitar kertas cakram yang mengandung bahan aktif steroid (Tabel 1). Daya hambat steroid terhadap pertumbuhan bakteri $V$. harveyi berbeda nyata $(\mathrm{P}<0.05)$ antar dosis (Tabel 1$)$. Semua dosis yang diujikan menunjukkan penghambatan tubuh bakteri, bahkan pada dosis ekstrak yang terendah (10 ppm). Semakin tinggi dosis ekstrak, maka cenderung semakin tinggi pula diameter hambat yang ditunjukkan, namun untuk dosis 10 hingga 5.000 tidak menunjukkan perbedaan. Walaupun daya hambat steroid sudah mulai kelihatan 
dari konsentrasi $10 \mathrm{ppm}$, tetapi luas zona hambat bebas bakteri yang ditunjukkan hingga konsentrasi $5.000 \mathrm{ppm}$ jauh lebih rendah dibanding zona hambat antibiotik Erythromicin dosis rendah (10 ppm). Dosis tertinggi ekstrak steroid (10.000 ppm) memiliki kemampuan penghambatan yang sama dengan kontrol positif yaitu antibiotik Erythromicin dosis rendah (10 ppm) yaitu $18 \mathrm{~mm}$.

Tabel 1. Rata-rata zona hambat bakteri Vibrio harveyi pada berbagai dosis ekstrak steroid dari teripang pasir

\begin{tabular}{lc}
\hline Dosis steroid $(\mathrm{ppm})$ & Zona hambat $(\mathrm{mm})$ \\
\hline (Kontrol negatif) & $0.000 \pm 0.000^{\mathrm{d}}$ \\
10.000 & $18.000 \pm 1.000^{\mathrm{a}}$ \\
5.000 & $9.000 \pm 0.000^{\mathrm{bc}}$ \\
1.000 & $7.167 \pm 0.7638^{\mathrm{b}}$ \\
500 & $6.500 \pm 0.5000^{\mathrm{b}}$ \\
100 & $7.167 \pm 0.7638^{\mathrm{b}}$ \\
10 & $8.167 \pm 2.4664^{\mathrm{b}}$ \\
Antibiotik & $18.000 \pm 1.000^{\mathrm{a}}$ \\
Erythromicin & \\
ppm & \\
\hline
\end{tabular}

Umumnya organisme laut menghasilkan senyawa yang berupa metabolit primer maupun sekunder. Metabolit yang dihasilkan pada suatu jenis organisme tersebut dipengaruhi oleh faktor lingkungan (Sonjak et al., 2005), oleh karena itu spesies yang sama pada habitat yang berbeda memungkinkan menghasilkan senyawa yang berbeda pula. Terdapat berbagai senyawa yang diperoleh ekstraksi teripang pasir. Dhinakaran \& Lipton (2014) memperoleh senyawa triterpene glycosida dan aglycon pada $H$. atra, sedangkan Uma \& Parvathavarthini (2010) mengidentifikasi senyawa organik ester dan alcane, seperti Pentadecane, Heptadecane, Eicosane, Heneicosane, dan Docosanedari teripang Temnopleurus alexandri. Pada penelitian ini, senyawa yang khusus diidentifikasi adalah steroid. Jumlah yang diperoleh adalah $0.065 \%$ dari ekstrasi yang dilakukan. Hal ini membuktikan pendapat Minale et al., (1996) bahwa steroid dan triterpenoid oligoglikosida (kadang berikatan dengan sulfat) merupakan senyawa yang dominan didapatkan sebagai metabolit sekunder dari teripang dan bintang laut. Rendemen steroid yang diperoleh ini $(0.065 \%)$ tergolong rendah disebabkan tingginya kadar air daging teripang segar yaitu sekitar $87,03 \%$ (Karnila et al., 2011).
Dalam melakukan ekstraksi, terdapat berbagai bahan pengekstrak yang dapat digunakan, bergantung pada sifat bahan aktif yang akan diperoleh. Pada penelitian yang dilakukan oleh Ridzwan et al., (1995), diujikan tiga pengekstrak yang berbeda, yaitu lipid, metanol, dan PBS. Dari penelitian tersebut, ekstrak PBS ternyata membuktikan kemampuan penghambatan yang terbaik. Sedangkan penelitian dari Shakouri et al. (2014) pada uji Spot dengan ekstrak metanol-air menunjukkan penghambatan yang lebih baik dibandingkan dengan tiga pengekstrak lain yang diujikan dengan kertas cakram yaitu menggunakan pengekstrak yang bersifat hidrofilik dan lipofilik (kloroform, metanol dan nhexane).Tampaknya masing-masing pengekstrak mengeluarkan senyawa dengan komposisi yang berbeda, sehingga kemampuan antibakterial masingmasing senyawa tersebut tidak memberi pengaruh. Dalam proses ekstraksi, bahan aktif akan terlarut oleh zat pengekstrak yang sesuai sifat kepolarannya. Pada penelitian ini, aseton digunakan sebagai larutan pengestrak. Aseton adalah pelarut yang baik untuk mengekstrak bahan aktif (Al-Ash"ary et al., 2010). Hal ini sejalan dengan Karnila et al., (2011) yang melakukan pemisahan konsentrat protein pada teripang menggunakan aseton.

Senyawa hasil ekstraksi dalam penelitian ini terbukti bersifat antibakterial karena menunjukkan kemampuan pengahambatan tumbuh baik pada bakteri gram positif maupun negatif. Menurut Lay (1994), terbentuknya zona hambat bebas bakteri melalui pengamatan daerah jernih di sekeliling kertas cakram membuktikan adanya daya kerja antimikrobial. Bagaimana steroid dapat menghambat pertumbuhan bakteri dijelaskan oleh Lysko \& Morse (1980), yaitu melalui penghambatan bakteri dalam mengkonsumsi oksigen dan metabolisme glukosa. Pada penelitian tersebut dijelaskan bahwa kemampuan penghambatan penyerapan oksigen oleh bakteri Neisseria gonorrhoeae tampaknya terkait dengan konfigurasi molekul steroid. Gugus lipofilik pada molekul dapat meningkatkan inhibisi, sebaliknya gugus hidrofilik akan mengurangi penghambatan.

Pada penelitian ini terlihat kemampuan penghambatan ekstrak terhadap bakteri masih rendah bila dibandingkan antibiotik. Sebagai kontrol positif, penelitian ini menggunakan antibiotik Erythromicin 10 ppm, penghambatan tumbuh bakteri yang diperoleh menunjukkan kemampuan penghambatan yang sama pada perlakuan ekstrak teripang dosis 
30 Indriyani Nur et al.

JURNAL SAINS dan INOVASI PERIKANAN / Journal of Fishery Science and Innovation

Vol. 3, No. 1, 26-31, Januari 2019

tertinggi, yaitu $10.000 \mathrm{ppm}$. Kemampuan antibakterial yang cenderung jauh lebih rendah dari antibiotik yang dihasilkan dalam penelitian ini memiliki kesamaan dengan penelitian yang dilakukan oleh Villasine (2000) yang menggunakan ekstrak teripang Parastichopus parvimensis. Zona hambat yang ditunjukkan oleh bahan aktif dari ekstrak tersebut juga masih rendah dibandingkan antibiotik ampicillin dan tetracyclin.

Dari data di atas dapat disimpulkan bahwa teripang pasir $H$. scabra yang diambil dari perairan Atowatu, Sulawesi Tenggara mengandung bahan aktif steroid dan mampu menghambat pertumbuhan bakteri $V$. harveyi. Walaupun pada dosis tertinggi yang diujikan (10000 ppm) menunjukkan penghambatan yang lebih rendah dibandingkan antibiotik Erythromicin 10 ppm, namun ekstrak steroid ini sudah menunjukkan penghambatan pada semua dosis yang diujikan, bahkan pada dosis minimum yakni 10 ppm. Olehnya teripang pasir tersebut berpotensi untuk pengembangan industri farmasi maupun obat-obatan penyakit udang/ikan.

Ucapan Terima Kasih: Ucapan terima kasih disampaikan kepada Direktorat Pendidikan Tinggi atas bantuan dana, demikian pula kepada Saudara Nasir yang membantu terlaksananya penelitian ini.

\section{DAFTAR PUSTAKA}

Abad MJ, Bedoya LM, Bermejo P. 2011. Marine Compounds and their Antimicrobial Activities. In: A Méndez-Vilas (ed.). Science Against Microbial Pathogens: Communicating Current Research and Technological Advances. Microbiology Book Series Vol. 2, Formatex Research Center, Spain. pp. 1281-1291

Al-Ash"ary MN, Supriyanti FT, Zackiyah. 2010. Penentuan pelarut terbaik dalam mengekstraksi senyawa bioaktif dari kulit batang Artocarpus heterophyllus. Jurnal Sain dan Teknologi Kimia 1(2): 150-158.

Datta D, Talapatra SN, Swarnakar S. 2015. Bioactive compounds from marine invertebrates for potential medicines - An overview. International Letters of Natural Science 34: 42-61. https://doi.org/10.18052/www.scipress.com/ILN.3 4.42 .

Dhinakaran DI, Lipton, AP. 2014. Studies on the bioactivity of Holothuria atra extracts collected from the South east coast of India. International Journal of Biology and Biological Sciences 3(1): 6-11.

Gowda NM, Goswami U, Khan MI. 2008. Purification and characterization of a T-antigen specific lectin from the coelomic fluid of a marine invertebrate, sea cucumber (Holothuria scabra). Fish \& Shellfish Immun. 24(4): 450-458. doi: 10.1016/j.fsi.2008.01.002.

Ibrahim M. 2001. Isolasi dan uji aktivitas biologi senyawa steroid dari lintah laut, Discodoris sp. [Tesis]. Bogor: Program Pascasarjana Institut Pertanian Bogor.

Karnila R, Astawan M, Sukarno, Wresdiyati T. 2011. Karakteristik konsentrat protein teripang pasir (Holothuria scabra J.) dengan bahan pengekstrak aseton. J Perikanan dan Kelautan 16(2): 90-102.

Lysko PG, Morse SA. 1980. Effects of steroid hormones on Neisseria gonorrhoeae. antimicrobial agents and chemotherapy 18(2): 281-288.

Mohammadizadeh F, Ehsanpor $\quad$ M, Afkhami M, Mokhlesi A, Khazaali A, Montazeri S. 2013. Evaluation of antibacterial, antifungal and cytotoxic effects of Holothuria scabra from the North Coast of the Persian Gulf. J Mycol Med. 23(4): 225-229.

Murniasih T. 2003. Metabolit sekunder dari spons sebagai bahan obat-obatan. Oseana 27(3): 27-33

Nofiani R. 2008. Urgensi dan mekanisme biosintesis metabolit sekunder mikroba laut. Jurnal Natur Indonesia 10(2): 120-125.

Parenrengi A, Suryati E, Ahmad T. 2002. Potensi sponge penghasil bakterisida dan fungisida alami belum banyak dimanfaatkan. Warta Penelitian Perikanan Indonesia 8(3): 10-15.

Ridzwan BH, Kaswandi MA, Azman Y, Fuad M. 1995. Screening for antibacterial agents in three species of sea cucumber from coastal areas of Sabah. Gen. Pharma. 26(7): 1539-1543.

Riris ID. 1994. Steroid dalam kerang hijau [Tesis]. Bogor: Program Pascasarjana Institut Pertanian Bogor.

Shakouri A., Nematpour F, Adibpour N, Ameri A. 2014. The investigation of anti-bacterial activity of Holothuria leucospilota sea cucumber extracts (body wall, guts and white strings) at Chabahar Bay in Oman Sea. Environmental Studies of Persian Gulf 1(2):135-140. 